\title{
Modelling the time to detection of urban tuberculosis in two big cities in Portugal: a spatial survival analysis
}

\author{
C. Nunes, ${ }^{*}$ B. M. Taylor ${ }^{\dagger}$ \\ *Centro de Investigação em Saúde Pública, Escola Nacional de Saúde Pública, Universidade NOVA de Lisboa, \\ Lisbon, Portugal; 'Faculty of Health and Medicine, Lancaster University, Lancaster, UK
}

S U M M AR Y

SETtING: Portuguese National Tuberculosis Control Programme.

OBJECTIVE: To examine delays in tuberculosis (TB) diagnosis using a spatial component in two highincidence cities, Lisbon and Oporto, in Portugal, a low-incidence country.

DESIGN: A retrospective nationwide study was conducted based on official TB data between 2010 and 2013 to analyse diagnostic delays at the lowest administrative level (freguesias) using spatial survival analyses, taking into account individual level covariates. RESULTS: Median diagnostic delays in Lisbon $(n=2706$ cases) and Oporto $(n=1883)$ were respectively 62 (range 1-359, mean 81.01) and 60 days (range 1-3544, mean 79.5 ). In both cities, case detection rates initially rose until 50 days, then stabilised but rose again at about
200 days. Diagnostic delay was significantly shorter among males and human immunodeficiency virus positive individuals in both cities, but significantly longer among migrants in Lisbon. There is evidence of spatial correlation between freguesias; different spatial patterns were observed in diagnostic delays and in likelihood of case detection.

CONCLUSION: These results are concordant with existing literature. The two study areas present considerable spatial variations in diagnostic delay, highlighting the fact that large cities should not be treated as homogeneous entities. The potential of spatial survival methods in spatial epidemiology is highlighted.

KEY WORDS: tuberculosis; delay; detection; spatial survival; epidemiology
ALTHOUGH TUBERCULOSIS (TB) IS a serious and potentially fatal disease that leaves a large global footprint, it is both curable and preventable. In 2014, 9.6 million people fell ill with TB and 1.5 million died from the disease. ${ }^{1}$ In last two decades, although the number of new cases and therefore the number of deaths have decreased, further research should be conducted for TB elimination. ${ }^{1} \mathrm{~TB}$ notification rates in the European Union (EU) have been declining at a mean annual rate of $4.4 \%$ since 2006 , but with wide variations between and within countries. ${ }^{2}$ In medium-to-low-incidence Western European countries, a stable or upward trend in TB incidence has been observed in some large cities, and a decline in other areas. For example, TB incidence in 2009 was 23.4 per 100000 population in Paris and 44.4/100 000 in London, compared with countrywide rates of respectively 8.2 and 14.8/100 000 in France and the United Kingdom. ${ }^{3}$ In the United Kingdom in 2013, TB was concentrated in the most deprived populations, with $70 \%$ of cases residing in $40 \%$ of the most deprived areas, ${ }^{4}$ the majority in large cities. TB tends to be more prevalent in and around urban centres, mainly because the known risk factors for the disease (e.g., drug use, alcoholism, human immunodeficiency virus [HIV], migration, homelessness) ${ }^{5}$ are more concentrated and amplified in the urban context. Urban environments promote interactions between individuals from all parts of society, creating opportunities for TB transmission.

Delays in diagnosing TB play a key role in the transmission of bacilli, increasing infectivity in the community, the risk of more advanced disease states at presentation, morbidity and mortality. ${ }^{6-8}$ Ideally, time to TB diagnosis should be no more than 3-4 weeks in smear-positive TB patients. ${ }^{9}$ The literature suggests that diagnostic delay varies widely between countries, ${ }^{7}$ and that it has increased in some EU countries in recent years. ${ }^{4}$

Classical risk factors for diagnostic delay, such as sociodemographic characteristics, substance use (drugs and alcohol), place of residence, comorbidities and access to health services, have been found to have differing and even contradictory impact in different studies. ${ }^{7}$ Even within a single city, there may be wide variations between neighbourhoods with respect to

Correspondence to: Carla Nunes, Centro de Investigação em Saúde Pública, Escola Nacional de Saúde Pública, Universidade NOVA de Lisboa, Av Padre Cruz, 1600-560, Lisbon, Portugal. e-mail: cnunes@ensp.unl.pt

Article submitted 5 November 2015. Final version accepted 2 May 2016. 
the sociodemographic characteristics of residents and level of social support, among other things, that could potentially affect the time to diagnosis. Social and environmental factors are expected to be more similar in two neighbouring areas of a city than in two areas that are far apart. ${ }^{10}$ While several studies have addressed the issue of diagnostic ${ }^{7-9,11,12}$ and other delays, ${ }^{13,14}$ no study has considered a possible spatial pattern in delays.

In the last decade, Portugal has witnessed a slow but consistent decrease in notified $\mathrm{TB}$ incidence; however, it still has one of the highest incidences in the EU (>20/100 000 as of 2014). ${ }^{15}$ Previous studies have shown huge space-time heterogeneity at the subnational level, reporting particularly high incidence in the Lisbon and Oporto areas, ${ }^{16,17}$ which are responsible for the majority of cases in Portugal, consistent with the patterns observed for urban TB in low-incidence countries.

The goal of the present study was to characterise and analyse TB diagnostic delay in two large cities, Lisbon and Oporto, both of which are high TB incidence areas located in a low-incidence country. Our emphasis is on modelling spatial variations in diagnostic delay at the freguesia (small administrative units in Portugal) level in cases diagnosed between 2010 and 2013, taking into account individual characteristics. The study focuses on possible spatial heterogeneity in patterns of delay in the two cities using 1) exceedance probability mapping to indicate areas of excessive delay, after taking into account individual population characteristics; and 2) maps showing the probability that delay will exceed a certain threshold.

\section{METHODS}

Data

Data were provided by Portugal's National Tuberculosis Control Programme (NTP); only TB cases diagnosed from January 2010 to December 2013 on the Portuguese mainland were included in the study. The NTP is supported by a nationwide information surveillance system based on compulsory TB notification by health professionals. Since 2000, the surveillance system has been evaluated on a yearly basis according to World Health Organization (WHO) guidelines, and it is considered reliable (84\% detection rate in $2014^{1}$ ).

Patient information available at the individual level included sex (female/male), age (years), drug use (yes/ no), alcohol abuse (yes/no), incarceration (yes/no), homelessness (yes/no), HIV positivity (yes/no) and migrant status (yes/no). The national TB database contains information on the place of residence of cases at the freguesia level. In the case of homeless patients, the freguesia of the health service where the case was reported is recorded.
The two study areas were defined based on circles with a radius of $30 \mathrm{~km}$, with their centre in the Lisbon and Oporto freguesias (respectively 177 and 230 freguesias), including central areas and various periurban and rural areas. Diagnostic delay was defined as the time in days between the onset of symptoms (self-reported) and TB diagnosis by the health services. To exclude implausible and extreme values, only delays between 0 and 365 days were considered.

Ethics committee approval and informed consent were not required, as the data were based on an official national surveillance system and had been previously anonymised.

\section{Statistical methods}

After a descriptive approach at the individual (delay and covariates) and freguesia levels (median delay), we used standard survival analyses ${ }^{18}$ extended to include spatially correlated random effects (frailties) $)^{19,20}$ to model delay time. This took into account extra spatial variations in outcomes using a combination of individual-level covariates and ecologicallevel spatially correlated effects. Our final model was a flexible parametric proportional hazards model. ${ }^{19}$ To model the relationship between age and reporting delay, a cubic B-spline function was used. ${ }^{21 *}$

Using this model, we summarised the effect on delay time due to individual risk factors in tables and mapped the unmeasured environmental risk to highlight city areas where the likelihood of diagnosis is lower than expected, taking into account the individual characteristics of the people in that area.

All analyses were conducted using $\mathrm{R}$ software (spatsurvpackage) (R Core Team. R: A Language and Environment for Statistical Computing. R Foundation for Statistical Computing. Vienna, Austria, 2014). ${ }^{22}$

\section{RESULTS}

\section{Descriptive statistics}

Between 2010 and 2013, 3536 TB cases in the Lisbon area experienced diagnostic delays ranging from 0 to 365 days, $2706(76.5 \%)$ of whom had complete records on all of the covariates of interest. In the Oporto area, the corresponding numbers were 2419 and $1883(77.8 \%)$ cases. Diagnostic delay at the individual level in the Lisbon area was a minimum of 1 and a maximum of 359 days (median 62, mean 81.01). Similar values were reported in Oporto, at respectively 1 and 354 days (median 60, mean 79.5). Table 1 presents the descriptive statistics of individual characteristics of TB cases in the Lisbon and Oporto areas. TB cases in Lisbon tended to be slightly younger than in Oporto (mean age 44.16 years,

\footnotetext{
* For more details please contact the corresponding author.
} 
Table 1 Descriptive statistics for Lisbon and Oporto areas

\begin{tabular}{lcc}
\hline & Lisbon & Oporto \\
Variables & $n(\%)$ & $n(\%)$ \\
\hline $\begin{array}{l}\text { Sex } \\
\text { Female }\end{array}$ & $1028(38.0)$ & $676(35.9)$ \\
Male & $1678(62.0)$ & $1207(64.1)$ \\
Alcoholic & & \\
Yes & $322(11.9)$ & $253(13.44)$ \\
No & $2384(88.1)$ & $1630(86.56)$ \\
Intravenous drug user & & $107(5.7)$ \\
Yes & $197(7.3)$ & $776(94.3)$ \\
No & $12509(92.7)$ & $25(1.3)$ \\
Prison inmate & & $858(98.7)$ \\
Yes & $32(1.2)$ & \\
No & $12674(98.8)$ & $25(1.3)$ \\
Homeless & & $1858(98.7)$ \\
Yes & $45(1.7)$ & $175(9.3)$ \\
No & $2661(98.3)$ & $1708(90.7)$ \\
HIV positivity & & $1814(96.3)$ \\
Yes & $495(18.3)$ & $69(3.7)$ \\
No & $2211(81.7)$ & \\
Migrant & $1972(72.9)$ & \\
No & $734(27.1)$ & \\
Yes & & \\
\hline
\end{tabular}

HIV = human immunodeficiency virus.

median 42 , range $0-112$ vs. mean age 47.01 years, median 46, range 0-100) (Table 1).

Figure 1 shows the median delay in each freguesia for both study areas. The median diagnostic delay at the freguesia level in Lisbon was 65 days (mean 69.79, range 21-178.5). In Oporto, the median delay was 65 days (mean 73.4, range 13-304). Not all freguesias provided data on diagnostic delay (see white areas on the map).

\section{Spatial survival analyses}

Table 2 shows the estimated fixed effects in our model. The effect of age (using a cubic B-spline function) on the risk of diagnosis is shown in Figure 2C (easier to interpret). Due to the nature of the study event (being diagnosed), relative risk ( $R R$ ) values $>1$ should be seen as 'good' (and $<1$ as 'poor').

These results show that the RR of a case being

Table 2 Estimated RRs and 95\% Crls for Lisbon and Oporto*

\begin{tabular}{|c|c|c|c|}
\hline & & $\begin{array}{c}\text { Lisbon } \\
\text { RR }(95 \% \mathrm{Crl})\end{array}$ & $\begin{array}{c}\text { Oporto } \\
\text { RR }(95 \% \mathrm{Crl})\end{array}$ \\
\hline Sex & Male $^{+}$ & $1.19(1.09-1.29)$ & $1.18(1.07-1.3)$ \\
\hline Alcoholic & $\mathrm{No}^{+}$ & $1.03(0.91-1.18)$ & $1.02(0.88-1.18)$ \\
\hline \multicolumn{4}{|l|}{ Intravenous } \\
\hline drug user & $\mathrm{No}^{+}$ & $0.96(0.82-1.16)$ & $0.82(0.65-1.04)$ \\
\hline Prison inmate & $\mathrm{No}^{+}$ & $1.13(0.77-1.62)$ & $1.11(0.74-1.76)$ \\
\hline Homeless & $\mathrm{No}^{+}$ & $1.02(0.75-1.43)$ & $0.64(0.44-1)$ \\
\hline $\mathrm{HIV}+$ & $\mathrm{No}^{+}$ & $0.85(0.76-0.95)$ & $0.81(0.69-0.99)$ \\
\hline Migrant & Yes $^{+}$ & $0.87(0.80-0.96)$ & $1.01(0.78-1.29)$ \\
\hline$\sigma$ & & 1.26 (1.19-1.39) & $1.32(1.21-1.44)$ \\
\hline$\varphi$ & & 3490 (1618-7143) & $2874(1363-5843)$ \\
\hline
\end{tabular}

* RRs $>1$ are associated with shorted diagnostic delays; RRs $<1$ are associated with longer delays. It should be noted that the effect of age is not indicated in this table (see Figure 2)

${ }^{+}$Class for each estimation is presented (all binary variables).

$\mathrm{RR}=$ relative risk; $\mathrm{Crl}=$ credibility interval; $\mathrm{HIV}=$ human immunodeficiency virus
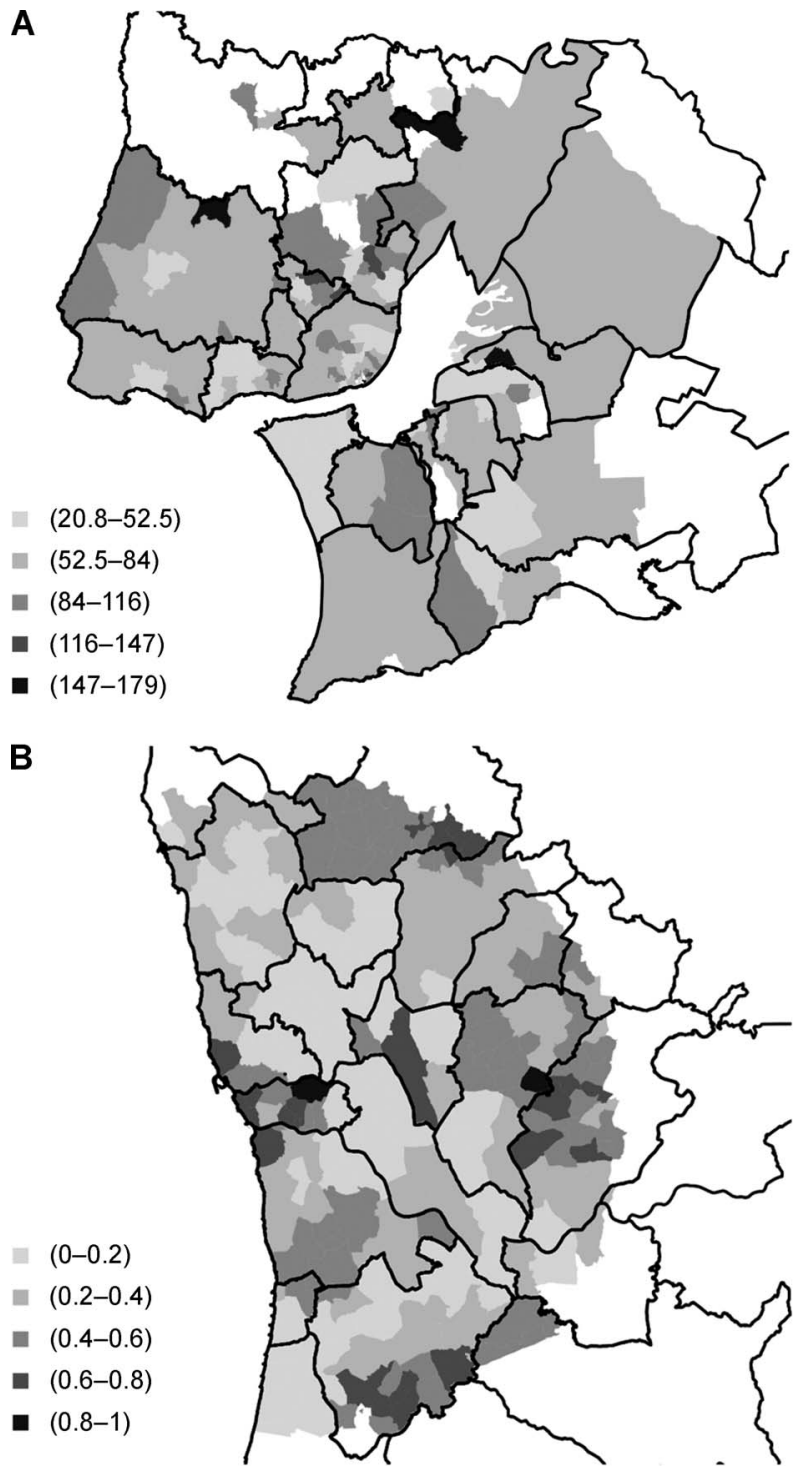

Figure 1 Median delay by freguesia; A) Lisbon area, B) Oporto area.

diagnosed more rapidly was significantly higher in males than in females in both cities, with no evidence of difference between the two cities. In both cities, there was little difference in $\mathrm{TB}$ detection rates in alcoholics and non-alcoholics. Infected intravenous drug users tend to be diagnosed more rapidly than non-users, and case detection in this subgroup was more rapid in Oporto than in Lisbon; however, these differences were not statistically significant.

Incarcerated individuals tended to be diagnosed more slowly than non-inmates, but this was not significant. With regard to homelessness, in Lisbon infected homeless individuals were likely to take longer to be diagnosed, but this difference did not attain significance; in Oporto, homeless individuals were diagnosed significantly more rapidly than the non-homeless. In both cities, TB in populations with HIV was diagnosed significantly more quickly than in non-HIV populations, with similar RRs in each case. 

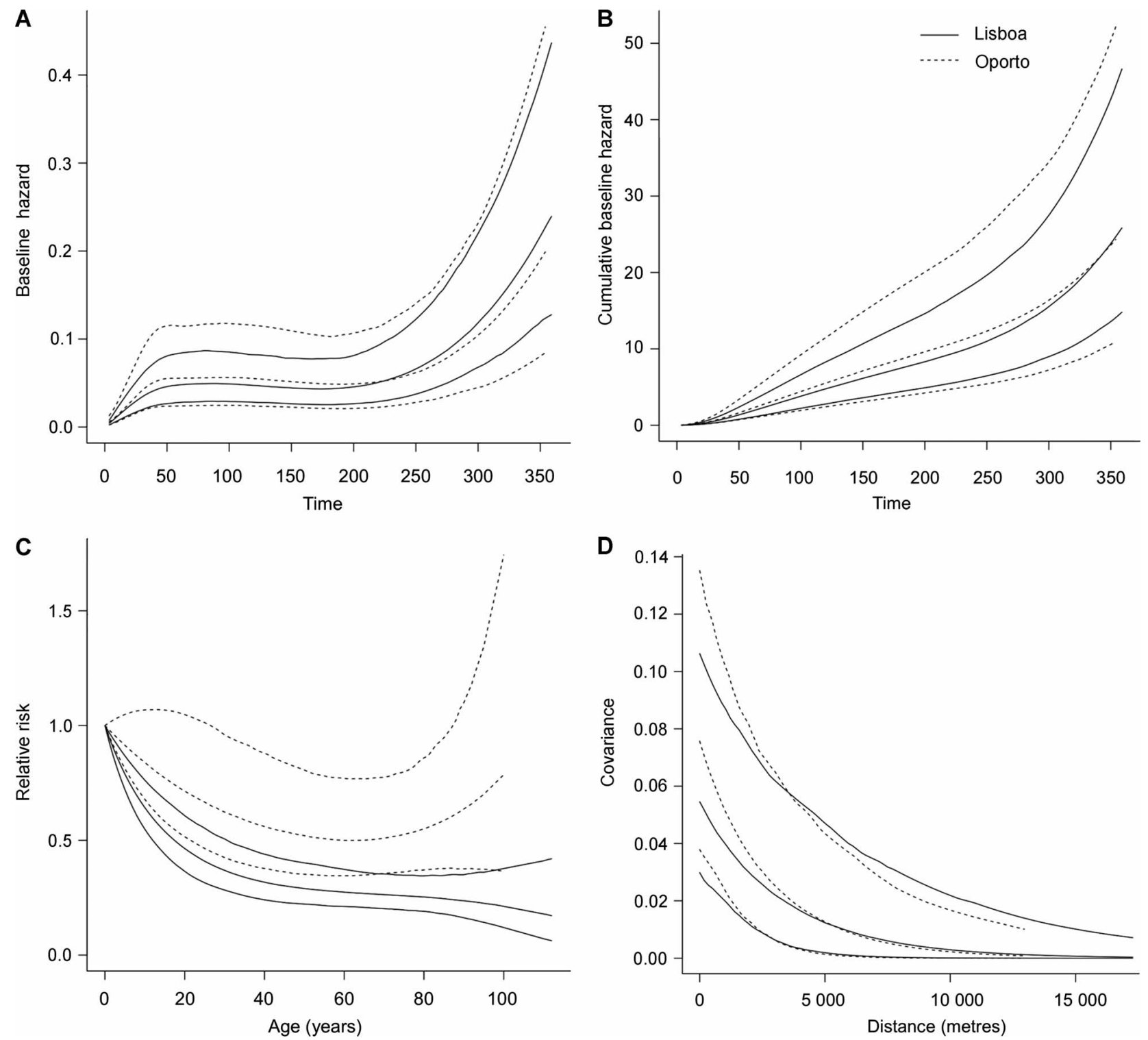

Figure 2 A) Estimated baseline hazard. B) Estimated cumulative baseline hazard. C) Relative risk as a function of age. D) Posterior covariance function of spatial effect, Y. These plots show the posterior median and $95 \%$ confidence intervals for each city.

In Lisbon, case detection rates were significantly slower in migrants than in the Portuguese-born, whereas in Oporto there was no difference between the two groups.

As regards the effect of age, the two cities show very different trends: in Lisbon there was a marked difference in detection rates between the young and the old, with cases aged $<20$ years being diagnosed significantly more rapidly than the remainder of the population; in Oporto, detection rates were fairly uniform across the ages, but children aged $<10$ years were diagnosed slightly more rapidly than the rest of the population (Figure 2C).

Baseline hazard functions show that in both cities case detection rates initially rose until about 50 days, then levelled off before starting to rise again at about 200 days (Figure 2A). Figure 2B shows the baseline cumulative hazard, which can be interpreted as the expected number of notified TB cases up to a given time if those events were repeatable, covariates and spatial random effects in the model being set at zero. Figure 2D gives the posterior covariance function for each city, which shows that there is evidence of spatial correlation between freguesias up to a distance of a few kilometres; however, freguesias around $5 \mathrm{~km}$ apart were largely independent. The median radius of freguesias (considered as circles of equivalent area) was $1155 \mathrm{~m}$ for the Lisbon study area and $1272 \mathrm{~m}$ in Oporto; the estimated spatial correlation therefore implies that most first-order neighbours were correlated in both cities, but with higher order correlations being present in the inner city areas, where freguesias are smaller.

Figure 3 shows exceedance probability maps for covariate-adjusted RRs (plots A and C) and the probability that the expected delay would exceed 60 
A

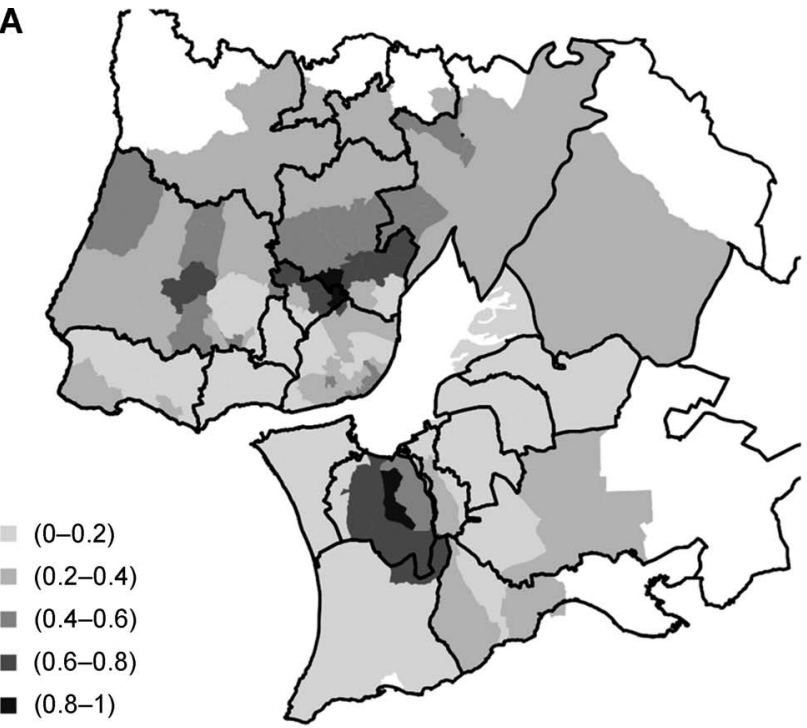

C

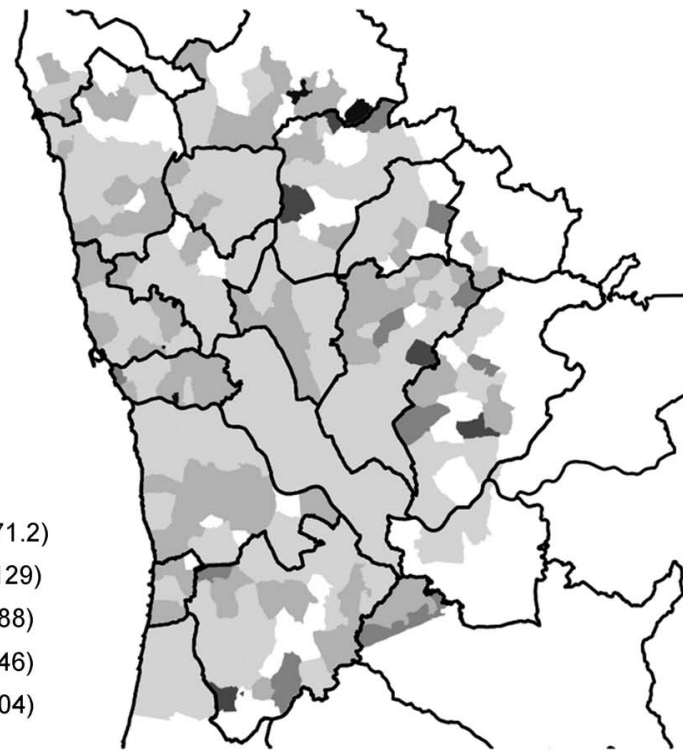

B

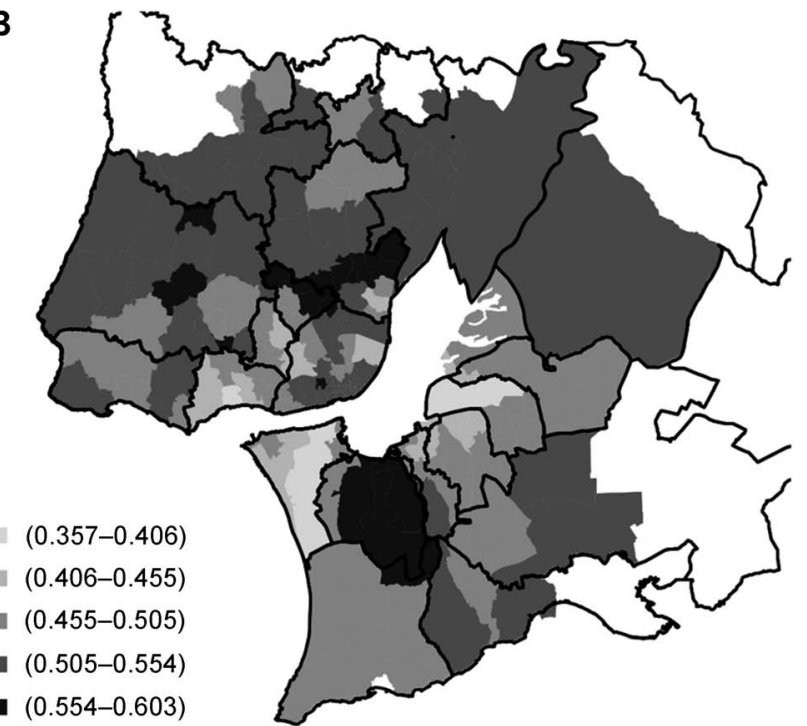

D

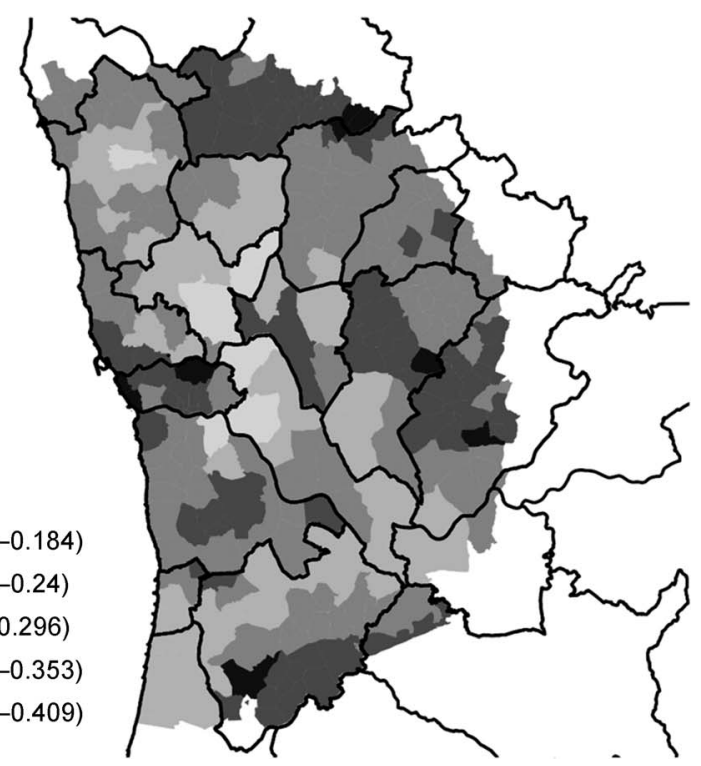

Figure 3 Top row: results from Lisbon, bottom row: results from Oporto. A) Plot of $P[\exp \{Y\}<0.85]$ (the probability that the covariate-adjusted relative risk is less than 0.85 ); B) plot of $E[S(60)]$ (the predicted probability that the delay to diagnosis will exceed 60 days in a Portuguese male aged 40 years with no other risk factors). Respective plots for Oporto: subfigures C) and D).

days for the most common risk profile, namely a Portuguese male aged 40 years with no other risk factors (plots B and D).

The plots on the left show that the probability of the covariate-adjusted RRs of case detection is $<0.85$. After taking into account the population characteristics in each freguesia of TB patients likely to affect time to diagnosis in that area, darker freguesias indicate areas with more substantial average delays than those that are lighter. Similar plots for other population subgroups would look the same, but the probability scale would be different; e.g., for females aged 40 years with no other risk factors, the probability scale ranges from 0.418 to 0.653 in Lisbon and from 0.169 to 0.465 in Oporto.

The plots on the right show the predicted proba- bility that time to diagnosis exceeds 60 days for a Portuguese male aged 40 years with no other risk factors; it should be noted that the spatial patterns in the left and right hand plots are different. Both the left and right hand plots show areas of potential concern from a public health perspective: the main difference is that the left-hand plots (Figure 3A and 3C) have taken into account individual covariates. Higher probabilities in Figure 3A and 3C indicate areas where delays are unusually long, given the characteristics of patients recorded in these areas; this raises the issue of whether there is a variable, undetected in the present study, that may explain these patterns-and which could be targeted by future public health initiatives. 


\section{DISCUSSION}

The median delay in TB diagnosis in the Lisbon area was 62 days, while in Oporto it was 60 days; there are considerable spatial variations in delays in both areas. Our results are consistent with the literature from other $\mathrm{EU}^{8}$ and industrialised countries. ${ }^{23} \mathrm{~A}$ previous study conducted in Portugal using similar covariate data between 2000 and 2009 reported a delay of 55 days at the national level; however, that study did not examine spatial variations. ${ }^{12}$

There is some evidence in the literature to suggest that the Oporto area may have more effective TB public health policies than Lisbon: TB incidence is falling more rapidly in this area, ${ }^{15}$ suggesting better practices (or medical awareness), also evidenced by a lower median delay. Could the differences in delay in these two regions be due to differences in the presence of risk factors in the populations? Both areas have similar population characteristics, being largely male, non-alcoholic, non-drug users, non-inmates and nonhomeless. Greater differences were observed in HIV prevalence and in migrant status (respectively 81.7 $90.7 \%$ and $27.12-36.6 \%$ ). The relationship between $\mathrm{HIV}$ and TB is well established in the literature, ${ }^{5}$ and Couceiro et al. identified a relationship between TB incidence and migrant status in Lisbon, which is relatively weak in Oporto. ${ }^{17}$

Our findings suggest that the total delay in diagnosing a case, comprising the sum of patient and health system delays, is lower in males, HIVpositive individuals and non-migrants than in other recognised subpopulations at risk of TB. These results are concordant with the literature, and are also associated with high-incidence risk groups. ${ }^{6}$ As the two cities are located in the same country, both have a similar culture, health care systems, laws and other contextual factors. In Lisbon, there appears to be a shorter diagnostic delay in Portuguese nationals that is not observed in Oporto. In Oporto, detection rates in homeless individuals are shorter, and younger individuals are more quickly diagnosed; there are also fewer differences between the old and the young than in Lisbon. Regarding the other variables (alcoholism, drug use or incarceration), the associated low frequencies can (or not) justify the absence of ?1 statistical significance.

Although the two study areas were relatively small, the spatial variations in delay across both areas are large. As shown in Figure 3, in Oporto longer delays were observed in the city centre, surrounded by a second zone (dormitory areas) around the centre with relatively shorter delays, after which the delays increased again in areas further away from the city centre. In Lisbon, a different pattern was observed, with longer delays in the city centre and in some dormitory areas, but not others. Note the difference in scales between Figure $3 \mathrm{~B}$ and $\mathrm{D}$; the estimated probability that diagnostic delay will exceed 60 days in a Portuguese male aged 40 years with no other risk factors is much higher in Lisbon compared with Oporto. No similar studies were found in the literature: only studies on urban areas and/or between countries were found. ${ }^{3,4,8}$ It is interesting to compare maps showing median delay times (Figure 1), which are more spatially random, with the spatial component of the model after adjusting for individual covariates (Figure 3), which shows a different pattern.

We conclude therefore that when examining time to diagnosis among TB cases, large cities should not be treated as single homogeneous entities, but rather as complex structures at the subcity level. As well as those covariates at the individual level examined in this study, delays in diagnosis may be due to other unobserved individual attributes that influence a person's health-seeking behaviour (and/or likelihood of being detected by the health system) and also to unobserved population interactions and other characteristics. These are now being reflected in the spatial random effects component.

One potential limitation of this study is related to the definition of the outcome variable, i.e, time to diagnosis as the time period between a self-reported variable (time of symptom onset), which is subject to recall bias, and a health system variable (date of diagnosis). As these are common epidemiological biases with known consequences, ${ }^{24}$ we excluded extreme delays (194 cases, representing $3.3 \%$ of all cases).

Another study limitation is the missing values; as TB health services in Portugal are sparsely distributed in space, each responsible for several freguesias, we assumed that the lack of data was related to the performance of the health services and was unlikely to significantly affect our spatial variation estimates. Lack of data due to non-presentation of patients at health facilities is more difficult to assess, but it was observed that our selected cases had sociodemographic characteristics that are similar to those of excluded cases.

The method of analysis proposed in this study can be used with more complex censored data (not applicable here), and to analyse other diseases.

\section{CONCLUSION}

Our study results are consistent with the literature. In both cities, we found that the correlations between diagnostic delay and sex and HIV status were statistically significant and with effects sizes in the same direction; however, the two cities present different challenges with respect to age and migrant status. On the whole, cases in Oporto seem to be diagnosed earlier. However, the goal of diagnosing 
the majority of cases within 4 weeks is currently far from being achieved in the two study areas.

Even after accounting for individual characteristics likely to affect time to diagnosis, there is substantial regional variability across both cites. More detailed studies with additional covariates that take into account individual and health system delay components should be conducted. Without this information, it is unclear how best to use public resources to further reduce delays. The potential of spatial survival analysis for modelling time-to-event data in spatial epidemiology is well demonstrated here.

\section{Acknowledgements}

The authors thank the coordinators of the National Programme for Tuberculosis Control for access to data from the Tuberculosis Surveillance Database. The study was partially supported by Fundação para a Ciência e a Tecnologia/Ministério da Educação e Ciência, Lisbon, Portugal (PTDC/SAUSAP/116950/2010 and SFRH/BSAB/1421/2014).

Conflicts of interest: none declared.

\section{References}

1 World Health Organization. Global tuberculosis report, 2015. WHO/HTM/TB/2015.22. Geneva, Switzerland: WHO, 2015.

2 de Vries G, Aldridge R W, Cayla J A, Haas W H, Sandgren A, van Hest N A, Abubakar I. Epidemiology of tuberculosis in big cities of the European Union and European Economic Area countries. Euro Surveill 2014; 19: 20726.

3 European Centre for Disease Prevention and Control. Urban tuberculosis control in the European Union. Stockholm, Sweden: ECDC, 2012.

4 Public Health England, Tuberculosis in the UK. 2014 report. London, UK: Public Health England, 2014.

5 Rieder H L. Epidemiologic basis of tuberculosis control. Paris, France: International Union Against Tuberculosis and Lung Disease, 1999.

6 Sreeramareddy C, Panduru K V, Menten J, Van den Ende J. Time delays in diagnosis of pulmonary tuberculosis: a systematic review of literature. BMC Infect Dis 2009; 9: 91.

7 Storla D G, Yimer S, Bjune G A. Systematic review of delay in the diagnosis and treatment of tuberculosis. BMC Public Health 2008; 8: 15 .

8 World Health Organization. Diagnostic and treatment delay in tuberculosis. An in-depth analysis of the health-seeking behaviour of patients and health system response in seven countries of the Eastern Mediterranean Region. WHO-EM/ TDR/009/E. Geneva, Switzerland: WHO, 2006.
9 Lambert M L, Van der Stuyft P. Delays to tuberculosis treatment: shall we continue to blame the victim? Trop Med Int Health 2005; 10: 945-946.

10 Ompad D C, Galea S A, Caiaffa W.T, Vlahov D. Social Determinants of the health of urban populations: methodologic considerations. J Urban Health 2007; 84 (3 Suppl): i42-53.

11 Gele A, Bjune G, Abebe F. Pastoralism and delay in diagnosis of TB in Ethiopia. BMC Public Health 2009; 9: 5.

12 Filipe P A, Gomes D, Nunes C, Silva M, de Sousa B, Briz T. Delay in diagnosis of pulmonary tuberculosis in Portugal. Proceedings of the $27^{\text {th }}$ International Workshop on Statistical Modelling, 16-20 July 2012, Prague, Czech Republic. http:// www.academia.edu/15052432/Delay_in_diagnosis_of_ pulmonary_tuberculosis_in_Portugal. Accessed June 2016.

13 Balabanova Y, Radiulyte B, Davidaviciene E, et al. Survival of drug resistant tuberculosis patients in Lithuania: retrospective national cohort study. BMJ Open 2011; 1: e000351.

14 Ajagbe O B, Kabair Z, O’Connor T. Survival analysis of adult tuberculosis disease. PLOS ONE 2014; 9: e112838.

15 Direção-Geral da Saúde. Programa Nacional para a infeção VIH/SIDA e Tuberculose. Dia Mundial da Tuberculose, 24 March 2016. Oral presentation. https://www.dgs.pt/emdestaque/dia-mundial-da-tuberculose-24-de-marco6.aspx [Portuguese]. Accessed June 2016.

16 Areias C, Briz T, Nunes C. Pulmonary tuberculosis space-time clustering and spatial variation in temporal trends in Portugal, from 2000 to 2010: an updated analysis. Epidemiol Infect J 2015; 143: 3211-3219.

17 Couceiro L, Santana P, Nunes C. Pulmonary tuberculosis and risk factors in Portugal: a spatial analysis. Int J Tuberc Lung Dis 2011; 15: 1445-1454.

18 Cox D R, Oakes D. Analysis of survival data. London, UK: Chapman and Hall, 1984.

19 Royston P, Parmar M K. Flexible parametric proportionalhazards and proportional-odds models for censored survival data, with application to prognostic modelling and estimation of treatment effects. Stat Med 2002; 21: 2175-2197.

20 Banerjee S, Carlin B P, Gelfand A E. Hierarchical modeling and analysis for spatial data. $2^{\text {nd }}$ ed. London, UK: Chapman and Hall/CRC, 2014.

21 Rosenburg P S. Hazard function estimation using B-splines. Biometrics 1995; 51: 874-887.

22 Taylor B M, Rowlingson B S. spatsurv: an R package for Bayesian inference with spatial survival models. J Stat Software [in press].

23 Sherman L F, Fujiwara P I, Cook S V, Bazerman L B, Frieden T R. Patient and health care system delays in the diagnosis and treatment of tuberculosis. Int J Tuberc Lung Dis 1999; 3: 10881095.

24 Bonita R, Beaglehole R, Kjellström T. Basic epidemiology. $2^{\text {nd }}$ ed. Geneva, Switzerland: World Health Organization, 2006. 
Contexte : Programme National de lutte contre la Tuberculose du Portugal.

OBJECTIF : Caractériser le retard au diagnostic de la tuberculose (TB) dans deux villes à incidence élevée au sein d'un pays à faible incidence : Lisbonne et Porto, Portugal, en incluant une composante spatiale.

SCHÉMA : Une étude rétrospective nationale a été réalisée, basée sur des données TB officielles, entre 2010 et 2013 ; en modélisant les retards au niveau administratif le plus bas (grâce à des analyses de survie spatiale), nous avons tenu compte des covariables au niveau individuel.

RÉSULTATS : Le retard au diagnostic dans la région de Lisbonne ( $n=2706$ cas) est d'une médiane de 62 jours (fourchette 1-359; moyenne 81,01) et de 60 jours (fourchette 1-3544; moyenne 79,5) à Porto $(n=1883)$. Dans les deux villes, le taux de détection des cas augmente initialement jusqu'à 50 jours, puis se stabilise et augmente à nouveau autour de 200 jours. Le retard à l'identification des cas est significativement plus faible pour les hommes et pour les individus positifs au virus de l'immunodéficience humaine dans les deux villes, mais significativement plus long pour les migrants à Lisbonne. Il y a donc une preuve de corrélation spatiale entre freguesias, et différents profils spatiaux ont été observés en termes de retard et de chance de détection des cas.

CONCLUSION : Ces résultats sont en accord avec la littérature. Les deux zones d'étude présentent d'importantes variations spatiales en termes de retard de diagnostic, ce qui souligne le fait que les grandes villes ne doivent pas être traitées comme des entités homogènes. Cette étude montre le potentiel des méthodes de survie spatiale en épidémiologie spatiale. marco de referencia: El Programa Nacional de Control de la Tuberculosis de Portugal.

o B JETIV O: Caracterizar el retraso en el diagnóstico en dos ciudades con alta incidencia de tuberculosis (TB), en un país con baja incidencia de la enfermedad, a saber: Lisboa y Oporto en Portugal. El análisis comportó un componente espacial.

MÉTODOS: Se llevó a cabo un estudio retrospectivo de ámbito nacional a partir de los datos oficiales sobre la TB del 2010 al 2013; se tuvieron en cuenta las covariables individuales modelizando los retrasos a una escala administrativa inferior (mediante análisis espaciales de supervivencia).

RESULTADO S: El retraso del diagnóstico de la TB en la zona de Lisboa tuvo una mediana de 62 días, con un margen entre 1 día y 359 días y un promedio de 81,01 días ( $n=2706$ casos); en Oporto la mediana fue 60 días, con un margen entre 1 día y 3544 días y un promedio de 79,5 días $(n=1883)$. En ambas ciudades la tasa de detección de casos aumentó inicialmente durante 50 días, luego se estabilizó y aumentó de nuevo después de 200 días. El retraso en la detección de los casos fue significativamente más corto en los hombres y en las personas infectadas por el virus de la inmunodeficiencia humana en ambas ciudades, pero fue significativamente más prolongado en los migrantes en Lisboa. El estudio reveló indicios de una correlación espacial entre las freguesias (divisiones administrativas) y se encontraron diferentes perfiles espaciales en los retrasos y el riesgo de detección de casos.

CONCLUSIÓN: Estos resultados concuerdan con otras publicaciones científicas. Las dos zonas de estudio presentaron amplias variaciones espaciales, lo cual destaca el hecho de que las grandes ciudades no se deben considerar como entidades homogéneas. Se demuestra la utilidad de los métodos de supervivencia espacial en los estudios de epidemiología espacial. 
Queries for jtld-20-09-18

1. Author: DISCUSSION, para 2: "the associated low frequencies can (or not) justify the absence of statistical significance." meaning? Ed 